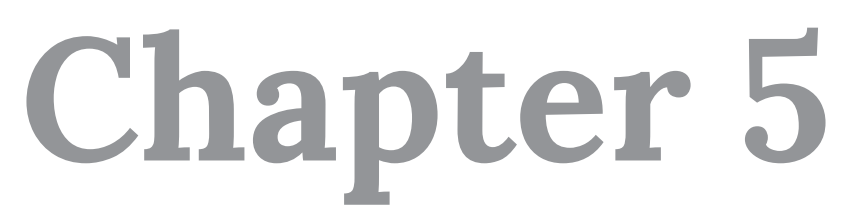

Heritage denunciation and heritage enunciation? A postcolonial discourse on state prioritisation of heritage in South Africa

\title{
Thabo Manetsi
}




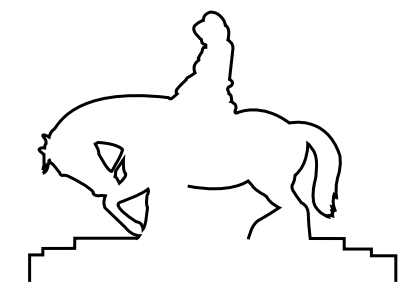

Struggles around culture and difference in South Africa have historically constituted a powerful domain of political resistance, whereby culture or ethnicity was a shorthand for political, social and economic claims...these claims are increasingly being enacted in the sphere of heritage and are themselves underpinned by the state failure over equity, access to resources, and recognition. ${ }^{1}$

$\mathrm{T}$ his article takes its lead from $\mathrm{PhD}$ research on 'State Prioritisation of Heritage: Issues of Governmentality, Heritage Management South Africa'. State Prioritisation of Heritage entails processes of governmentality were certain pasts (heritage) are selected, legitimised and authorised as official heritage of the nation/state in the present. ${ }^{2}$ Similarly the notion of 'Denunciation and Enunciation of Heritage', in relation to State Prioritisation of Heritage draws on the discourse of governmentality were select past/s are privileged over others and proclaimed official heritage in the post-colonial South Africa.

Building on Foucault's thesis on governmentality, in the recent postcolonial writings on the subject matter, Laurajane Smith introduces the term "Authorised Heritage Discourse" to expand the analysis of the various regimes involved in heritage governance. She argues that heritage involves a cultural process of meaning making, mediation, selective amnesia (the politics of forgetting and remembering), expert influence and codification, and a naturalising effect. She elaborates further: 
$[\mathrm{H}]$ eritage places ... create, legitimize and disseminate their own particular cultural and social meanings, and are thus themselves part of, and not separate from, the 'heritage process' of meaning making. As heritage sites are managed, the performance of what is chosen to be remembered and forgotten about the past is enacted, and its conservation and presentation to the public will affect "sense of place" and other experiences. However, this process is obscured and redefined as external to the process of heritage because of the way value is assumed as immutable and innate - management and conservation become things that are done to sites and places, but are not seen as organically part of the meaning-making process of heritage itself. ${ }^{3}$

Both notions, 'governmentality' and 'Authorised Heritage Discourse', provide lenses to probe the extent of state influence and dominance in the formalisation of heritage through policy and institutions to determine the enunciation of 'official' heritage but conversely denunciation of heritage in the present.

The Liberation Heritage Project prioritised heritage in the postcolonial South Africa serves as a reference point to issues of heritage denunciation and enunciation in relation to state intervention in heritage management. In this essay, I will illustrate and interrogate the question of political instrumentality informing the denunciation and enunciation of heritage resources in relation to political uses of heritage as part of the postcolonial discourse on heritage management. Ashworth \& Tunbridge have raised some critical questions on the issues of the 'Intrinsic value: the social and political uses of heritage', such as why a particular interpretation of heritage is promoted, whose interests are advanced or retarded, and in what kind of milieu was it conceived and communicated ${ }^{4}$ It is precisely the purpose of this essay, to further interrogate the rationality and implications of the deployment and mobilisation of political and policy instruments

3 See Laurajane Smith, Uses of Heritage, 88.

$4 \quad$ See Gregory John Ashworth \& John E. Tunbridge, Pluralising Pasts: Heritage, Identity and Place in Multicultural Societies, 41. 
informing the current approach to heritage management, such as the colonial and apartheid influences on the postcolonial experience of the governance of heritage resources.

\section{Framing political instrumentality: The denunciation and enunciation of heritage resources in postcolonial South Africa}

In March-April 2015, the much publicised controversy over the violent destruction and removal of colonial monuments and apartheid statues at various locations in South Africa, sparked by the University of Cape Town's (UCT) \#RhodesMustFall campaign, clearly demonstrated public dissent and denunciation of the colonial past and heritage. This happened in a context of prolonged frustrations about lack of transformation in post-apartheid South Africa. This is not to be confused with media reports about the desecration of colonial monuments linked to elements of criminal and political opportunism by certain factions of society. These violent acts tend to set a precedent of permanent obliteration of history and past for future reference, yet simultaneously underpin the construction of history and heritage in the present. The current state of denunciation of colonial heritage epitomises public dissonance with colonial symbols and what they represent. The kind of reception that a monument and memorial in the public domain receives from its targeted audience is largely dependent upon that audience's historical and socio-cultural background. A historical and socio-cultural background encompasses lived experiences and behaviours of a people, in this case the unequal distribution of power along the basis of race, gender, class, ethnicity, age and even sexual orientation under apartheid. ${ }^{\mathbf{5}}$ 5 See Pepi Leistyna, Arlie Woodrum \& Stephen A. Sherblom. Breaking Free: The
Transformative Power of Critical Pedagogy, 3. 
Coombes asserts that

... many of the buildings or other structures that have been proclaimed national monuments by the National Monuments Council have more negative than positive connotations for the majority culture ...what does it mean, for example, to preserve the Cape Dutch architecture and slave quarters of Groot Constantia, built on slave labour and thriving as a profitable vineyard to this day. ${ }^{6}$

She further argues, that

... the Voortrekker monument is the Afrikaner nationalist symbol most closely identified with the apartheid regime and remains highly contested in the democratic South Africa... the monument attest to its historical value as a vestige of a separatist system and others argue for its removal...this monument, which represents the former apartheid state and the myth that South Africa belongs to the Voortrekkers and their descendants. ${ }^{7}$

Following the violent destruction of colonial heritage in 2015 in South Africa, the then Minister of Arts and Culture, Mr Nathi Mthethwa, held nationwide consultative meetings and public hearings with politicians and civil society organisations on the contestations in the heritage landscape. As an outcome of the consultative meetings, about 20 resolutions were adopted and a 10-member task team was set up to examine the recommendations of the meetings further. The task team has since presented a report of its findings to the Minister but it is still to be made public. However, Minister Mthethwa commented that the majority of respondents were against the vandalism and destruction of statues during the public hearings. Also, there were some examples given of erection and installation of new monuments juxtaposed to 'old and offensive statues'.

6 See Annie E. Coombes, Symbolic Restitution, 34.

7 Annie E. Coombes, Translating the past: apartheid monuments in post-apartheid South Africa, 173-197.

8 Department of Arts and Culture, Report on Stakeholder Engagement on reflections by the Minister Nathi Mthethwa, 11. 
Public denunciation of colonial heritage elicits deep-seated questions: What would the ideal heritage symbols that resonate with the aspirations of the present generation look like? A simple response, to a much more complex situation, could be that the popular dissent against colonial and apartheid history inversely justifies the enunciation of the much-celebrated Liberation Heritage Project currently being prioritised in postcolonial South Africa. Heritage denunciation of the colonial and apartheid past further accentuates the politicisation of heritage through 'heritage erasures', aptly described by Pikirayi as:

... choices and decisions we make with regards to our own environmental contexts...this includes heritage erasures ... [ie] ... what we choose to save may be what we value, but it does not necessarily follow that what we destroy or choose not to keep, is valueless ... the current situation in the Middle East is an example ... sustainable heritage is about meeting the needs of the present and the future, not just preserving the past. ${ }^{9}$

Heritage symbols of the anti-colonial and anti-apartheid struggle (Legacy Projects such Freedom Park, Robben Island Museum, Mandela Museum and others) are inscribed on the cultural landscape juxtaposed to the colonial and apartheid heritage (Victorian and Dutch Architecture and monuments including the Voortrekker Monument amongst others). The idea of heritage enunciation and denunciation draws heavily on oppositional discourse where the juxta positioning of old (colonial and apartheid heritage) and new (postcolonial heritage) symbols counteract and stand in stark contrast to each other. Also the juxta positioning of old and new symbols along the idea of pastpresent alignment to achieve diverse cultural representation (social cohesion, national identity and 'common heritage') as an integral part of the postcolonial narrative tend to accentuate the notion of co-presence, where old and new symbols appear simultaneously almost in a complementary or oppositional manner within the same context (time and space). The unparalleled co-presence and binary

9 See Innocent Pikirayi, The Heritage We Want: Development, Sustainability and the Future of Africa by 2063. 
opposition of both the enunciation of the anti-colonial heritage (liberation heritage) and denunciation of colonial heritage mirrors the current political milieu of postcolonial thinking in relation to heritage management in South Africa.

The politics of transforming the heritage landscape in post-1994 South Africa witnessed the emergence of the idea of state prioritisation and enunciation of the liberation heritage as a site of memory, responding to, and confronting the legacy of the former repressive regimes for restorative justice particularly to honour and recognise the legacy of the political struggles for freedom against colonialism and apartheid. It is arguable that the framing of the "National Liberation Heritage Route' project as state prioritised heritage in postcolonial South Africa serves as a counter-narrative to colonial and apartheid heritage. The most prominent and popular signifiers of the liberation heritage in the democratic South Africa are a plethora of memorials and monuments such as Freedom Park, Robben Island Museum, Luthuli Museum, Nelson Mandela Museum, Ncome, Hector Petersen Memorial, and many others including statues, graves and places named after struggle icons. ${ }^{10}$

The introduction of Legacy Projects (post-1994), like some of the aforementioned state projects, are iconic fixtures of the evolving cultural landscape which serve to redress pastinequities. The Liberation Heritage Project has also manifested through a spate of media frenzy commemorative national events, festivities and celebrations. In the year 2012 South Africans witnessed the prioritisation of liberation heritage which occurred prominently juxtaposed to the muchprofiled centenary celebrations of the formation of the African National Congress (ANC) 100 years ago in 1912 as the oldest liberation movement in Africa. In the celebration of 20 years of democracy in 2014 since the attainment of freedom in 1994, new places and sites of liberation history have been unveiled. Of paramount importance is the passing of former President Nelson Mandela in December 2013 which spurred the abrupt and subsequent unveiling of his towering statue

10 South African Tourism, Tourism Satellite Report for the Financial year 2014/2015, 5-10. 
at the Union Buildings in Pretoria and his portrait at Parliament in Cape Town as symbols of honour to the iconic freedom fighter.

All these forms of state prioritisation of the liberation heritage have far reaching implications on the question of state-centric approaches to heritage management at political, policy and administrative levels in South Africa. This relates specifically to the mobilisation and deployment of state resources to advance the consolidation of the National Liberation Heritage Route project, as a flagship project of the post-apartheid and post-liberation South Africa.

The theme, liberation heritage, is a bold political statement which resonates with postcolonial thinking of how the state imagines the memorialisation and commemoration of the anti-colonial struggle in the present. In particular, the National Liberation Heritage Route project is perceived as a befitting memorial and commemorative project, which resonates with the hopes and aspirations of the majority South Africans who suffered under the repressive colonial and apartheid regimes. ${ }^{11}$ In this regard the National Liberation Heritage Route project is located within the discourse of transformation of the cultural landscape in the new South Africa and attempts to present the alternative history of untold narratives and historically suppressed experiences of the masses of South Africans who suffered under the siege colonial and apartheid regimes. On this point Marschall argues that

... new monuments and statues are necessary to 'tell the other side of the story'; to expose suppressed histories and preserve narratives of the past previously written out of the official historical record; to counter biased interpretations disseminated through the existing symbolic landscape; to celebrate the identity and achievements of societal groups previously marginalized; and lastly to acknowledge suffering and pay tribute to individuals or groups who lost their lives through acts of resistance. ${ }^{12}$

11 Department of Arts and Culture, Progress Report on the National Liberation Heritage Route Project, 3-5.

12 Sabine Marschall, Landscape of Memory: Commemorative Monuments, Memorials and Public Statuary in Post-Apartheid South, 16. 
For many who have traversed the cultural landscape of South Africa, it is still glaring to note the recurring dominant representations of colonial and apartheid conquest in the public domain which do not reflect the demography and diversity of South Africa. According to the draft National Heritage Transformation Charter "... the disparities amongst the various heritage institutions persist in the distribution and management heritage resources only highlights the perpetuation of the pre-1994 norms and practices privileging certain institutions at the expense of the previously disadvantaged institutions (PDIs) ..."13

Similarly, the non-profit organisation (NPO), the 'Direct Action Centre for Peace and Memory' pointed out:

... in Cape Town, where there are marks of victory against the native dotting the cultural landscape, there are no marks of victory against colonialism and apartheid...there is a gap in recognising those who fought apartheid in the city's cultural landscape. ${ }^{14}$

The rationalisation of both the ideological text and physical signifiers of liberation heritage in the public domain does not only reflect systematic curation and mediation of history and past by the state, but also underpins the deliberate inscription and positioning of an anti-colonial legacy in public consciousness and popular culture through the construction of heritage in the present for consumption by the current generation.

In the context of regime change and the politics of transforming the heritage landscape in the postcolonial South Africa, the promotion of liberation heritage is morphed and woven into grand, national narratives such as 'reconciliation', 'social cohesion', 'national pride', 'national identity', and 'nationhood' of an emerging 'democratic' state. For the state, heritage is arguably an opportunistic means to fulfil the social needs of the electorate, while simultaneously fostering the political goals of nation-building, reconciliation and unity, as well as

13 National Heritage Council, Draft National Transformation Heritage Charter, 4.

14 Direct Action Centre for Peace and Memory, Policy Dialogue: The Role of the ExCombatants in Memorialisation Processes in South Africa, 5-6. 
promoting the economic imperatives of development, employment creation and income generation, mostly through tourism. ${ }^{15}$ Thus, the impression created is that the National Liberation Heritage Route project serves as a political construction at the service of addressing broad political aspirations and objectives of post-apartheid South Africa. As Negri observed,

... when culture is closely linked to politics, cultural heritage becomes a vehicle for transformation of society...the political objectives for which the cultural heritage is used differ from one nation to another ...the cultural dimension may thus be used to legitimise political orientations. ${ }^{16}$

In this context, the National Liberation Heritage Route project has become a deliberate attempt to legitimise the recognition of anti-colonial history not only as 'official' heritage of the nation state but to serve as an instrument to entrench political ideals in a transforming state.

\section{Documenting and legitimising liberation heritage in South Africa and Africa}

The theme of liberation heritage has often been a site of profound interest and preoccupation in the geo-political space in postcolonial Africa and post-apartheid South Africa in particular. The notion of liberation heritage draws on the history and historiography of postcolonial thinking and writing about the political history of the struggle for emancipation against colonialism in Africa and apartheid in South Africa. Several renowned scholars and intellectuals, especially of African descent, have written extensively on the effects of the political instrumentality of colonial domination, in particular white domination and black subjugation, decolonisation, Pan-Africanism, post-colony, democracy, neoliberalism, social justice, political consciousness, transformation, and

\footnotetext{
15 Sabine Marschall, Landscape of Memory: Commemorative Monuments, Memorials and Public Statuary in Post-Apartheid South, 14.

16 Vinvent Negri, "Introduction to Heritage Law in Africa", 8.
} 
identity politics. ${ }^{17}$ These grand themes underpin the struggle discourse of several liberation movements and ambitious attempts aimed to restore and affirm 'African identity' in the global context. ${ }^{18}$

A substantial part of these postcolonial and post-apartheid writings and studies has been preoccupied with the important task of documentation and analysis of liberation history and theory, especially the interpretation and systematic recording of the memory and narratives of the struggle against the repressive colonial and apartheid orders. The volumes of the publication, The Roads to Democracy in South Africa by South African Democratic Education Trust (SADET), under the leadership of Ben Magubane, marks a first series of post-1994 scholarship writing on various topics and epochs of the liberation struggle in South Africa. Similarly, the publication by Ndlovu, the current Director of SADET project entitled, Heritage routes for the liberated South Africans: using oral history to reconstruct unsung heroes and heroines' routes into exile in the 1960s, presents alternative histories of the liberation struggle which have been largely undocumented. ${ }^{19}$ The research report entitled The Liberation Struggle and Liberation Heritage Sites in South Africa, commissioned by the NHC to the Human Sciences Research Council (HSRC - 15 November 2013) in South Africa, follows on from the previous works of SADET and also serves the same purpose of documentation of the liberation history in South Africa.

In the SADC region, the Hashim Mbita project regarding the documentation of the liberation history in Southern Africa was approved by the Southern African Development Community (SADC) Summit of Heads of States and Governments in Botswana in Mahmood Mamdani (1992), Achille Mbembe (2001) and many others.

18 See Senghor's Negritude (1930), Nkrumah's idea of the Organisation of African Unity (1961), Nyerere's Ujamaa (1962), and most recently Mbeki's popularisation of African Renaissance (1998).

19 Sifiso Mxolisi Ndlovu, "Heritage routes for the liberated South Africans: Using Oral History to Reconstruct Unsung Heroes and Heroines' Route into Exile in the 1960s", 3. 
August 2005. ${ }^{20}$ The result was the recent publication (2014) entitled Southern African National Liberation Struggles by Hashim Mbita, a former Brigadier-General and Executive - Secretary (1974-1992) of the Liberation Committee of the Organisation of African Unity (OAU). The publication attempts to document the history of the liberation struggle of the Southern African Region through collection, cataloguing and compiling of oral texts in SADC Member States and outside the region. ${ }^{21}$ The National Liberation Heritage Route Project in South Africa is part of the SADC joint initiative.

In contrast, Saunders has cautioned that, in more recent writings, especially of the more popular kind, one often finds 'romanticisation and triumphalism' on the part of those whose movements emerged victorious. He further argues that

... triumphalist history either ignored or minimised difficult issues in the past, such as the imprisonment and torture of activists in exile...it tends to be uncritical, assuming that criticism would somehow bring the struggle itself into disrepute..$^{22}$

In post-apartheid South Africa, the work by cultural institutions ${ }^{23}$ who have taken the task of documenting and safeguarding the history and heritage of the liberation struggles in South Africa, demonstrate the importance of the Liberation Heritage Project as a priority project for the nation state. These institutions have been preoccupied with the theme of the liberation heritage in a bid to transform the heritage landscape by presenting alternative narratives of the resistance struggle to the

20 Report of the African Union, SADC Summit of Heads of States and Governments in Botswana in August 2005, resolved to support and approve the Hashim Mbita project regarding the documentation of the liberation history in Southern Africa.

21 The Hashim Mbita Research Project, Southern African National Liberation Struggles, 2.

22 Nordic African Institute, Workshop report on "Documenting the History and Legacy of the Liberation Struggle in South Africa", 2, 11.

23 South African History Archive, Center for Popular Memory, National Oral History Project, Department of Arts and Culture, Department of Military Veterans, National Heritage Council, South African Heritage Resources Agency, the Nordic Africa Institute (Sweden), National Archives, National Library, Centre for the Study of Violence and Reconciliation, Nelson Mandela Centre of Memory, Nelson Mandela Museum. Freedom Park, Chief Albert Luthuli Museum, Mayibuye Archives, District Six Museum, Universities and many others 
dominant narrative of the colonial and apartheid orders. ${ }^{24}$ However, what has been sadly lacking, is state prioritisation of the digitisation and ownership of the digital archive of the liberation heritage archive. It is shocking to note that ownership rights of the digitised material of South Africa's liberation history, especially anti-apartheid records, are not in the custodianship of the state. It appears that the state has not yet prioritised enough resources towards the digitisation of the liberation heritage archive as part of heritage management. Lalu argues that there has been an increase in the digitisation of the liberation history in South Africa by multinational organisations and this has far reaching implications on ownership rights and claims by multinational organisations on South Africa's digital archive. ${ }^{25}$

In postcolonial states, in Africa and southern Africa in particular, there seems to be a concerted effort and political commitment by the former liberation movements, as the ruling party in government, to legitimize the legacy of the liberation struggle against colonialism as 'official' history and heritage of the nation state. This recurring pattern has been prevalent in several post-colonial states especially in the SADC region and elsewhere. Critics have observed that:

... former liberation movements, including the Popular Movement for the Liberation of Angola in Angola, the Front for the Liberation of Mozambique in Mozambique, the African National Congress in South Africa, the South West Africa People's Organisation in Namibia and the Chama Cha Mapinduzi in Tanzania at the helm of government in Zimbabwe, Namibia, Mozambique, Angola, South Africa and Tanzania, have maintained close ties rooted in common liberation histories and personal connections, and during times of crisis they draw on these linkages and solidarities. ${ }^{26}$

24 National Heritage Council, Draft National Transformation Heritage Charter, 4-5.

25 Premesh Lalu, The virtual stampede for Africa: Digitisation, Postcoloniality and Archives of the Liberation Struggles in Southern Africa, 4.

26 Sabelo Ndlovu-Gatsheni, "Reconstructing the Implication of Liberation Struggle History on SADC Mediation in Zimbabwe", 5. 
Strategic political alliances have been established amongst the former dominant liberation movements, which have influence in the SADC region. In each regime and political system it is evident that heritage is used as a rallying point to mobilise society, consolidate political power to advance political interests.

An important summit of the heads of political parties of former liberation movements was held in August 2011, in Namibia, which stressed

... the importance of identification, restoration and preservation of historical sites which are relevant to the liberation struggles' need for promoting the spirit of solidarity and cooperation amongst Africans in the context of the former liberation movements. ${ }^{27}$

Undoubtedly, the political position and commitment to safeguard the history of the liberation struggle is top on the agenda of former liberation movements in government in the SADC region. However, recurring dissonance and unavoidable disputes occur as a result of the tendency to impose certain histories with a bias towards the dominant narrative of former liberation movements at the helm of Government. Sometimes this dominance and bias of promoting and legitimising certain narratives over others tends to exclude and displace alternative histories, especially narratives of other former liberation movement who are not in the ruling governing party.

Consistent with the notion of the politicisation of heritage through technologies of governance and governmentality, Melber argues that:

... governments formed by the anti-colonial liberation movements, took control of the state machinery and reorganized themselves as political parties...their legitimacy to rule stemmed from their emergence from the decolonization process as representatives acting on behalf of the majority of the people...since then they have been able to strengthen their political dominance and maintain control over the state. ${ }^{28}$ parties of the former liberation movements, 02. 
In other words, the critical questions of hegemonic politics of domination and the politicisation of heritage, lying behind the ideological construction of the Liberation Heritage Project through state prioritisation of the struggle history, are inevitable. This is especially the case in the context of the 'dominant ideology thesis' in political uses of heritage. In particular, which dominant narrative will be privileged and for what purpose, in the context of governmentality and the current political milieu in South Africa?

\section{Governmentality and political enunciation of the liberation heritage}

The Liberation Heritage Project has emerged from remnants of the past into the present. A new trajectory has emerged in post-apartheid South Africa, where sharp focus and emphasis is on memorialisation and celebration of the struggle for freedom. Due consideration and attention must be given to Harrison's claim that

... heritage can both stimulate and act as a symbol of political struggle, and how ownership of heritage objects, places and practices might be considered to give their possessors political power. ${ }^{29}$

As a politically endorsed and state resourced 'official' heritage, the National Liberation Heritage Route project has found meaning and expression through elaborate official enunciations by the state at expedient political moments. Most notably, on four occasions in the successive years, 2011, 2012, 2013 and 2014, former President of the Republic of South Africa, Mr Jacob Zuma, underlined the Liberation Heritage Project and the development of graves and monuments of struggle heroes as priority projects for the nation in his State of the Nation Address (SONA). ${ }^{30}$ On the occasion of the State of the Nation Address in February 2011, President Jacob Zuma pronounced that

29 Rodney Harrison, Understanding the Politics of Heritage, 154.

30 State of the Nation Address by His Excellency Jacob G Zuma, President of the Republic of South Africa, at the Joint Sitting of Parliament, Cape Town - on the 10 February 2011 and 09 February 2012. 
... we [Government] will launch a programme celebrating National Icons and promote a National Liberation Heritage Route, to honour individuals who have made an enormous contribution to the liberation of our country. ${ }^{31}$

In the subsequent year, in 2012, in his State of the Nation Address, the President reiterated that

... as part of the promotion of social cohesion, this year we will undertake and continue many heritage projects ... museums and centers to be unveiled will include the 1980 Matola Raid museum in Maputo, the Ncome museum in Kwa Zulu-Natal, phase 2 of the Freedom Park museum and the Steve Biko heritage centre in Ginsberg in King Williamstown...we have also prioritized the homes and graves of former ANC Presidents and other national heroes including Thomas Maphikela, Lilian Ngoyi, Walter and Albertina Sisulu, Griffiths and Victoria Mxenge, Robert Sobukwe and others. ${ }^{32}$

Once again in the State of the Nation Address on 14 February 2013, President Zuma pronounced that

... this year marks the $50^{\text {th }}$ anniversary of the raid on Lilliesleaf Farm, the escape from Marshall Square as well as the start of the Rivonia Trail...A series of events are being planned throughout the year to mark the three events, culminating in a national commemoration on the $11^{\text {th }}$ of July $2013 .^{33}$

The authoritarian power of political instrumentality behind such fundamental enunciations by the head of state cannot be underestimated. Critics have observed that such pronouncements by the state about public representations through monuments and the accompanying unparalleled media coverage of these symbols are implicitly informed by the emancipatory postmodern and postcolonial

31 State of the Nation Address by His Excellency Jacob G Zuma, President of the Republic of South Africa, at the Joint Sitting of Parliament, Cape Town - on the 10 February 2011.

32 State of the Nation Address by His Excellency Jacob G Zuma, President of the Republic of South Africa, at the Joint Sitting of Parliament, Cape Town - on the 09 February 2012.

33 State of the Nation Address by His Excellency Jacob G Zuma, President of the Republic of South Africa, at the Joint Sitting of Parliament, Cape Town - on the 14 February 2013. 
discourses of the previously oppressed margin as it comes to the fore and expresses its identity. ${ }^{34}$ It is therefore the mandate and objective of the ANC-led government to deliberately foreground the liberation heritage in the public domain, as this aspect of heritage has been subject to marginalisation during colonialism and apartheid.

Amongst the aforementioned projects, state resources have been allocated towards the implementation and completion of the following projects, namely, the $2^{\text {nd }}$ phase of the Freedom Park Museum, Steve Biko Heritage Centre, Ncome Museum and the 1980 Matola Raid Museum in Mozambique. ${ }^{35}$ However, the latter project has since been reported to lack governance systems and inadequate management structure to support administrative operations due to insufficient funding. ${ }^{36}$ Tracking the status and progress of the implementation of these projects is important, as the state has made a pronouncement and pledged resources to support these prioritised projects.

Nonetheless, the political rhetoric by President Zuma not only profiles and positions the Liberation Heritage Project as a tangible construct of political imagination, but demonstrates the extent of political will and power to select and support an aspect of the past in a supposedly politically correct context. It is worth recalling that both the colonial and apartheid states once selected heritage resources that favoured and advanced their political interests in the past.

Another important point to consider is that political enunciations by the President mirror the inherent social compact and relationship involving the mobilisation of power from party politics into state administration (executive authority). This alignment is evident in the conformity of the President's pronouncement (the state) to the ANC's (party politics) position on issues of arts, culture, and heritage that "...

34 Sabine Marschall, Landscape of Memory, 16.

35 Department of Arts and Culture Presentation of Progress Report, Legacy Project of State of Nation Address and Liberation Heritage Route, at the Parliamentary Arts and Culture Portfolio Committee meeting, 25 April 2012.

36 Department of Arts and Culture Presentation of Progress Report, Legacy Project of State of Nation Address and Liberation Heritage Route, at the Parliamentary Arts and Culture Portfolio Committee meeting, 25 April 2012. 
a national memorial commemorating the liberation struggle will be erected, as it has outlined in the ANC Draft National Cultural Policy ..." ${ }^{\prime 37}$ Even the revised White Paper on Arts, Culture and Heritage draws heavily on the ANC's Draft National Cultural Policy (1994), stating that "... colonialism and apartheid neglected, distorted and suppressed the culture of the majority of South Africans ..."38

This kind of political alignment has attracted criticism amongst other former liberation movement and opposition political formations, such as the sentiment vehemently expressed by Prince Mangosuthu Buthelezi (Leader of the Inkatha Freedom Party - IFP and Member of Parliament) that

... on the surface it would seem that we both have the same interests at heart. He [President Zuma] is a Zulu, I am a Zulu...and he is proud of his cultural heritage...but President Zuma is also the President of the ANC, and he leads a party whose intention has always been to gain political hegemony and total dominance. ${ }^{39}$

The issue of political domination and the inherent selective amnesia through privileging certain signifiers of the historic past constitutes an integral aspect of postcolonial discourse around constraints and opportunities of addressing diverse representations. On this point Bhabha argues that

... postcolonial criticism bears witness to the unequal and uneven forces of cultural representation involved in the contest for political and social authority within the modern world order. ${ }^{40}$

This ties in well with Fanon's reference, 'The Pitfalls of National Consciousness', in what he has described as the

... national consciousness, instead of being the all-embracing crystallization of the innermost hopes of the whole people, instead

37 ANC, Draft National Cultural Policy 1994, 2-10.

38 ANC, Draft National Cultural Policy 1994, 2-10.

39 Address by Prince Mangosuthu Buthelezi (MP), Inkosi of the Buthelezi Clan and Traditional Prime Minister of the Zulu Monarch and Nation, April 2, 2013. 
of being the immediate and most obvious result of the mobilization of the people, will be in any case be only an empty shell, a crude and fragile travesty of what it might have been. ${ }^{41}$

In other words, the idea of inclusion and exclusion of others' heritage or culture within the framework of cultural diversity tends to undermine the state's efforts for national unity, where the intention in a typical postcolonial and democratic context such as in post-apartheid South Africa, is to establish signifiers for social cohesion, national identity, national unity and patriotism. To achieve multiculturalism in a political system through state prioritisation of the liberation heritage will require a substantial measure of appreciation and acceptance of political and cultural differences as well as tolerance which tends to be difficult to achieve.

The extent of the influence of politics in shaping the liberation heritage is re-hashed and re-articulated in various public platforms and social contexts. Most notably, the persistent politicisation of heritage and uses of heritage to achieve political goals, which tend to be unavoidable. In one of a series of speeches recorded verbatim in the Limpopo Province Legislature in September 2014, a member of the ANC highlighted:

... I want to emphasise to myself and all of us here and the public out there that we must start to argue that the African National Congress itself as the political party is the heritage of the South African people and the African struggle [APPLAUSE]...I want to state that the Freedom Charter states that this land belongs to all of us - black and white and further that the colour of a man"s skin is no more significant than the colour of his eyes...we want to argue that apartheid is a legacy, but it is a legacy which we want to forget...we want it to be put in the archives of history and never be re-loaned or introduced to our people except to remind them of the evils of apartheid...the African National Congress' main policy, as the liberation movement and body committed to nation-building, is to redress the imbalances of the past. ${ }^{42}$ 
These political sentiments and policy positions are prevalent especially in ANC-led provinces and municipalities, where a set of expectations is created and certain ideas entrenched - that the ANC-led government is a home for all regardless of varying political ideologies and cultural differences. This notion links well with the findings in a publication entitled, The Patronage Politics Divides Us: A Study of Poverty, Patronage and Inequality in South Africa by Ncebisi Ndletyana. In this publication Ndletyana shares insights into the unscrupulous extent of hegemonic politics in certain ANC-led municipalities plagued by patronage ties of blind loyalty, nepotism and prejudice, self-enrichment and reciprocal beneficiation. He argues that there is a tendency to pledge political support and allegiance to politicians, regardless of their morals and ethics, in positions of power who are likely to reciprocate the favour by allocating certain privileges and benefits only to those in society who pledged support initially. ${ }^{43}$

Most importantly, the mobilisation of political instrumentality that underpin the state prioritisation of the National Liberation Heritage Route illustrates the extent to which the power of politics tends to assume a governance position to inform heritage management, far beyond the limitations of structured state policy frameworks.

The notion of state prioritisation of the Liberation Heritage Project, as 'official' heritage of the nation state, is not immune from the discourse of contemporary uses of heritage by the state in the political process of nation building and forging a new national identity in South Africa. Political use of heritage is a common fixture of many political systems in nation states, clearly illustrated in the works of Benedict Anderson (1991), Stuart Hall (1998), and many others. 


\section{Uses of the liberation heritage at expedient political moments}

As part of postcolonial discourse of policy reforms for new heritage regimes, the National Heritage Resources Act (1999) has created enabling environment for implementing certain aspects of the liberation heritage. In particular Section 4 (g)(iii) and (g)(iv) of the National Heritage Resources Act (1999) makes specific reference to the declaration of sites "... graves of victims of conflicts and those associated with the liberation struggle ... graves of individuals designated by the Minister by notice in the Gazette."44 Through this piece of legislation the Ministry of Arts and Culture gazetted the declaration of several graves, as national heritage sites, of struggle icons such as Charlotte Maxeke, Helen Joseph and Lillian Ngoyi in 2010 and subsequently, in 2013, the graves of Rev Sefako Makgatho, Mr Josiah Gumede, Dr Pixley ka Isaka Seme, Dr Robert Sobukwe, Mr Stephen Biko and Dr Christiaan Beyers-Naude, were declared national heritage sites. ${ }^{45}$ The convenient use of policy to legitimise a select few national monuments and memorials has had far reaching consequences in privileging certain pasts over others. The inherent bias in the declaration of the select legacies of a few struggle icons and the exclusion of others, has attracted criticism broadly especially from opposition political formations such as the Democratic Alliance (DA), Inkatha Freedom Party (IFP), Pan African Congress (PAC) and United Democratic Movement (UDM), against the ruling party - the ANC. This also includes resentment and dissonance expressed by some alliance parties in the ANC, concerning the dominance of the ANC-led Liberation Heritage Project, such as the critique by members of NEUM:

... Well, we need to call a spade a spade: the ruling party looks after its own. Today liberation heritage is by and large a story about ANC icons from the past, with a nod towards Black Consciousness leader, Steve Biko, PAC icon, Robert Sobukwe, and one or two indigenes, such

$44 \quad$ National Heritage Resources Act no 25 of 1999.

45 South African Government News Agency, Graves of Struggle Heroines Declared Heritage Sites. 
as Klaas and Trooi Pienaar, whose remains were recently repatriated from Austria and reburied at Kuruman in the Northern Cape ... and more of the same is on the way...now, according to Paul Mashatile, the Minister of Arts and Culture, the graves of Charlotte Maxeke, Lillian Ngoyi, Helen Joseph, O. R. Tambo, Alfred Xuma, Pixley Ka Isaka Seme and Albert Luthuli, among others, are to be upgraded and declared national heritage sites ... in privileging its own, the ruling party has effectively erased that past in which the ANC is not inscribed, and that past in which it was challenged by a rival political tendency, as represented by the NEUM and associated organisations ... but that today's heritage landscape is a biased and exclusionary masternarrative focusing on ANC national heroes shouldn't surprise us, of course, as history, heritage and memory are always controlled and shaped by those in power ... what we have in South Africa is an official national heritage landscape that has been edited by the state through engineered silences and gaps in the liberation story - a deliberate distortion of history by omission. ${ }^{46}$

Similarly Michele Pickover, curator in the Department of Historical Papers at the University of the Witwatersrand (Wits), writes:

... the state and the ruling party lays claim, ownership and stewardship to South Africa's past and the 'liberation struggle' not under the guise of inclusiveness discourse... It is not about creating a common, inclusive identity but about creating a monolithic lens through which a certain kind of struggle history is given superiority and fostered. ${ }^{47}$

Inevitably the Liberation Heritage Project which is state funded through the ANC-led government will tend to project and profile the political interests of the ruling party in government, much to the dismay and exclusion of the narratives of other former liberation movements and political parties who serve in the government of national unity in South Africa.

46 NEUM report, Disinherited: Distorting Heritage by Omission, 11.

47 Pickover, "Disinherited: Distorting heritage by omission," in NEUM report, 12. 
The political and policy context that has shaped the emergence of the Liberation Heritage Project, as a flagship project of the nation state, draws its inception from a series of political and official state declarations. In 2012, the Department of Arts and Culture announced a set of key objectives during the staging of Heritage Day celebrations in the Northern Cape Province, under the theme "Celebrating the Heroes and Heroines of the Liberation Struggle in South Africa",48 which aimed to:

1. reaffirm and promote the significance of Liberation Heritage as part of the Cultural Heritage of South Africa;

2. use the Liberation Heritage as a vehicle to foster social cohesion, nation building, economic development, inclusive citizenship and an end to xenophobia and homophobia;

3. promote national identity that is self-conscious of its liberation heritage; and

4. promote unity in diversity among all sectors of the South African society.

These official statements of intent clearly not only define the extent of the uses of heritage at the service of contemporary South African politics, but epitomise the fundamental consequences of the expectations of the new political order for heritage management to fulfill certain national priorities of a developing nation. In this regard, the National Heritage Council concedes that “... expectations are high that the Liberation Heritage Route project will promote social and economic progress and that it will provide impetus for the development of cultural industries and cultural tourism." ${ }^{49}$ According to Ashworth et al (1996) and Heroines of the Liberation Struggle in South Africa, 2-3.

49 National Heritage Council, Presentation of National Liberation Heritage Route project at a Summit in the North West Province, 6. 
Heritage is used as a political resource in the creation or support of state at various spatial jurisdictional scales and the legitimation of their governments and governing ideologies. ${ }^{50}$

In this context, the political discourse on contemporary uses of heritage transcends the notion of heritage uses for the sake of conservation purposes only, but also advances the debate on the tendency of state to appropriate heritage for other uses in contemporary politics.

This phenomenon is prevalent in many other political systems and countries. Some African states affirm the pre-eminence of the cultural dimension to establish national identity. Negri observed that

... the acknowledgement of cultural values can thus be effected at the highest level of the legal standards which underpin the creation of the state thus the incorporation of the cultural priorities in the Constitution may correspond to different objectives...it may be from the need to use these foundations to build a national identity common to the different ethnic groups or the need to promote a dominant national culture that will compel recognition among the various communities of the state..$^{51}$

The notion of nation building and national identity in democratic South Africa further accentuates heritage uses as a rallying point to mobilise society, consolidate political power and advance political interests. For instance, the uses of heritage to engender a culture of national unity, reconciliation, social cohesion and, most recently, economic and infrastructure development in line with national priorities of a democratic South Africa, are prevalent. According to the proposed amendments in the White Paper on Arts, Culture and Heritage:

Developing an inclusive, cohesive, caring and proud society is pivotal to social transformation ... it requires eradicating all inequalities, exclusions and divisions of the past; and replacing it with a shared South African identity which incorporates diversity in a democratic 
dispensation; by directly translating the rights and responsibilities of both the state and its citizens into social reality. ${ }^{52}$

The notion of reconciliation and unity, which follow on from a negotiated settlement during the transition phase in 1994, has been systematically enacted in various state supported high profile events. During a symbolic ceremony in 2013 the former Minister of Arts and Culture, $\mathrm{Mr}$ Paul Mashatile unveiled a road linking the Voortrekker Monument and Freedom Park as a gesture of unity and bridging the past (apartheid state) and the present (democratic state). ${ }^{53}$ Subsequently, in 2014 the Minister of Arts and Culture, Mr Nathi Mthethwa, officiated the unveiling of a bridge linking the Ncome Memorial to the Voortrekker Monument, on Reconciliation Day (16 $6^{\text {th }}$ December 2014) as part of the state socialisation for unity and social cohesion. ${ }^{54}$ In this context, the idea of heritage use to forge and foster a new national identity and unity is consistent with the perceived conditions of a democratic dispensation amid the deeply entrenched and glaring reality of racism, homophobia, and xenophobia in South Africa.

The uses of heritage at national events which are state funded, also play to public consciousness and serve as a political instrument to mobilise support and legitimise the Liberation Heritage Project. Such political instrumentality has been partly realised through established platforms, including the much profiled year-long 2012 centennial celebrations of the formation of the ANC 100 years prior. In 2012, the Liberation Heritage Project featured prominently in the centenary celebrations marking the 100 year anniversary of the ANC as the oldest liberation movement in Africa. The prominent theme of the liberation heritage, which constituted an integral part of the centenary celebration, was carefully orchestrated through a systematic assemblage of public lectures, symbolic torch bearing processions and a myriad of festivities

52 Revised Draft White Paper on Arts, Culture and Heritage, 22.

53 Department of Arts and Culture 2013/2014 Budget vote speech by the Minister Paul Mashatile at the National Assembly,16 ${ }^{\text {th }}$ May 2013, http://www.dac.gov.za

54 Department of Arts and Culture, A Speech delivered by the Minister of Arts and Culture Mr Nathi Mthethwa at the occasion of the 'National Recociliati on Day', $16^{\text {th }}$ December 2014, Ncome Museum (KwaZulu Natal), www.dac.gov.za 
across South Africa, in celebration of the oldest liberation movement in Africa and its founding leaders. According to the ANC, the centenary celebrations seeks to

celebrate our [ANC] proud traditions, values and principles that earned our movement an indelible place in the hearts, psyche and soul of our people...it should reflect the ANC in all its facets and dimensions, for example, mass mobilization, the underground, armed struggle and international solidarity. ${ }^{55}$

In 2012, the African Union also endorsed the centenary celebrations of the ANC through a 'Decision on the Centenary of the African National Congress' at the General Assembly. ${ }^{56}$ For the past 20 years since the dawn of democracy, the ANC has reinvented itself as a political party rather than a liberation movement. However, the former liberationmovement-turned-ruling-party largely draws on the legacy of the anti-colonial and anti-apartheid struggle for credentials in order to socially mobilise the masses in contemporary South African politics. The struggle credentials of the ANC have earned the political party immense support amongst the masses in South Africa, and thus the liberation heritage is a popular choice for many South Africans.

In certain untimely events, such as the passing on of the world iconic leader Nelson Mandela in 2013, the notion of the liberation heritage once again received a substantial measure of prominence and media mileage. This also spurred the proliferation of heritage initiatives associated with Nelson Mandela, such as the unveiling of a towering bronze statue of Madiba (2014) at the Union Building by the Department of Arts and Culture, the grading and declaration of the 'Nelson Mandela Sites of Reconciliation and Memory' (2014) by the National Heritage Council, and most recently the launch of the 'Madiba Journey' mobile application in 2015 by the South African Tourism. 
Back in the Eastern Cape Province, the birth and burial place of Nelson Mandela, a special Cabinet resolution was taken to honour prominent leaders of the struggle as part of marking the 20 years of democracy and the branding of the province under the banner - 'Home of the Legends'.57 Most notably, the Cabinet resolved to honour Nelson Mandela, Chris Hani and O.R. Tambo amongst great leaders whose birth place is the Eastern Cape Province, as part of the commemorative programme of the liberation heritage and the 'Home of the Legends' campaign. ${ }^{58}$ Similar events occurred in various provinces across South Africa. Crucial to note here is not only the scaling up of an important memorial project such as liberation heritage, but the mounting of prominent personalities and icons of the liberation struggle as an embodiment of the political struggle, and thus as being an integral part of the composition of the Liberation Heritage Project.

The framing of the liberation heritage at expedient political moments has also occurred in various other ideological texts and inscriptions on the physical fabric of the cultural landscape. Post-apartheid South Africa has witnessed the politicisation and manifestation of heritage in the naming and renaming of places after struggle icons of the liberation struggle. Several towns, streets, buildings, city-scapes, and municipalities which constitute the cultural landscape attest to an abrupt upsurge of new place names aligned to struggle heroes and heroines. For example the Sol Plaatjie Municipality (Northern Cape province), the Nelson Mandela Museum (Eastern Cape province), Luthuli House (Gauteng province), O.R. Tambo International Airport (Gauteng province), Thabo Mbeki Drive (Limpopo province), Moses Mabhida Stadium (KZN province), Ngaka Modiri Molema Municipality (North West province), Fezile Dabi Municipality (Free State province) - the list is exhaustive.

57 Eastern Cape Provincial Legislature adopted a Cabinet resolution to honour prominent leaders of the struggle as part of marking the 20 years of democracy and the branding of the Province under the banner of the 'Home of the Legends' (2014). 
These commemorative initiatives of national stature exemplify the political context and conditions in which the Liberation Heritage Project finds profound meaning and prolific expression. Inversely, the legacy of the liberation struggle sets the terms and conditions which inform a particular political context for the celebration of the liberation heritage in the postcolonial and post-apartheid South Africa.

\section{Conclusion}

Heritage enunciation and denunciation has become a political currency for social mobilisation in postcolonial South Africa. Both the denunciation of colonial and apartheid heritage, as well as the enunciation of liberation heritage shows how heritage has been deployed in ways that challenge common or essentialised understandings of the notion and practice of heritage. As illustrated before, the Liberation Heritage Project is a deliberate attempt to legitimise anti-colonial history as 'official heritage' and a state sanctioned memorial project juxtaposed an assemblage of colonial and apartheid heritage formations in the democratic complex. In essence, the ideological construction of the Liberation Heritage Project places sharp focus on broad questions of political uses of heritage which tend to serve multiple purposes such as reclaiming and unearthing the suppressed histories of the anti-colonial struggle. Simultaneously, political uses of the legacy of the anti-colonial struggle are morphed into formations of a new nation state and national identity.

The far-reaching impact of state prioritisation of the Liberation Heritage Project rests in the state's acceding to the challenge of mastering the representation of diverse pasts and experiences of the struggle(s) against colonialism and apartheid. The consequences of 'selective amnesia' often have far reaching implications on in skewed or biased representations of certain narratives which may diminish the strides by the state - government of national unity - to achieve 'social cohesion' through recognition of diverse representation of broad narratives of the liberation struggle. Therefore, it is inevitable 
that in the scheme of power relations and imposition of authority by the state, certain heritages will be privileged over others and/or to the exclusion of still others. The question remains whether liberation heritage in South Africa will transcend traditional racial, ethnic, and economic boundaries, or simply reinforce these categories. Analysing these processes and the differing investments of social groups will allow for a fuller appreciation of the historical consciousness and geographic agency of these groups, including their vested interests in the Liberation Heritage Project.

\section{Bibliography}

Abercrombie, et al.

The Dominant Ideology Thesis. London: Allen and Unwin Hyman, 1980.

African National Congress (ANC). Draft National Cultural Policy, 1994.

Anderson, Benedict.

Imagined Communities: Reflections on the Origin and Spread of Nationalism. London: Verso Editions, 1980.

Appadurai, Arjun.

The Globalization of Archaeology and Heritage. Journal of Social Archaeology. United States of America, 2001.

Ashworth et al.

Dissonant heritage: The Management of the Past as a Resource in Conflict. London: Wiley and Sons, 1996.

Ashworth, Gregory John \& Brian J. Graham \& John E. Tunbridge.

"The uses and abuses of Heritage." In Heritage Museums and Galleries: An Introductory Reader, edited by Gerard Corsane. London: Routledge, 2005.

Ashworth, Gregory John \& John E. Tunbridge.

Dissonance and the Uses of Heritage. London: Wiley and Sons, 1996.

Ashworth, Gregory John \& John E. Tunbridge.

Pluralising Pasts: Heritage, Identity and Place in Multicultural Societies. London:

Pluto Press, 2007 
Baines, Gary.

"The Politics of Public History in Post-Apartheid South Africa." In History Making and Present Day Politics: The Meaning of Collective Memory in South Africa, edited by Hans Erik Stolten. Uppsala: Nordiska Afrikaininstitutet, 2007.

Baines, Gary.

"The Freedom Park Fracas and the Divisive Legacy of South Africa's Border War/ Liberation Struggle." Social Dynamics 35, no. 2(2009): 330-344.

Bhabha, Homi K.

"Introduction: Narrating the Nation." In Nation and Narration, edited by Homi K. Bhabha. London: Routledge, 1990.

Bhabha, Homi K.

The Location of Culture. London: Routledge, 1994.

Cabinet Memorandum of the National Liberation Heritage Route Project, Department of Arts and Culture, and the National Heritage Council, 2013, http:// www.dac.gov.za and http://www.nhc.org.za

Chris Hani District Municipality. Liberation Heritage Route: Icon Site Guide, Rhodes University Institute for Social and Economic Research, 2008.

Comaroff, Jean \& John L. Comaroff.

Millennia! Capitalism and the Culture of Neoliberalism, Durham and London: Duke University Press, 2001.

Coombes. Annie E.

"Translating the past: apartheid monuments in post-apartheid South Africa. London: Routledge." In History after Apartheid: Visual Culture and Public Memory in Democratic South Africa, edited by Annie E. Coombes, 173-197. NC: Duke University Press, 2000.

Coombes, Annie E.

History after Apartheid: Visual Culture and Public Memory in Democratic South Africa. NC: Duke University Press, 2003a.

Coombes, Annie E.

Symbolic Restitution. Johannesburg: Wits University Press, 2003b.

Danaher, Geoff, Tony Schirato \& Jenn Webb.

Understanding Foucault. London: Sage Publications Ltd, 2002. 
Deacon, Harriet, Sephai Mngqolo \& Sandra Prosalendis.

Protecting our Cultural Capital. Cape Town: HSRC Press, 2003.

Department of Arts and Culture (South Africa). Celebrating the Heroes and Heroines of the Liberation Struggle in South Africa, 2012a.

Department of Arts and Culture (South Africa). Presentation of Progress Report, Legacy Project of State of Nation Address and Liberation Heritage Route, at the Parliamentary Arts and Culture Portfolio Committee meeting, 25 April, 2012b.

Department of Arts and Culture (South Africa). Revised Draft White Paper on Arts, Culture and Heritage, p. 22, 2013.

Department of Arts and Culture (South Africa). Report on Stakeholder Engagement on reflections by the Minister Nathi Mthethwa, 2016.

Direct Action Centre for Peace and Memory. Policy Dialogue: The Role of the Ex-Combatants in Memorialisation Processes in South Africa, The Centre for the Study of Violence and Reconciliation - Transitional Justice Programme, Workshop Report, pp. 5-6, 2007.

Fanon, Frantz.

The Wretched of the Earth. New York: Grove Press, 1963.

Foucault, Michel.

Truth and Power. Selected Interviews \& Other Writings by Michel Foucault, 19721977, 1972.

"On Governmentality." Ideology and Consciousness 5(1979): 5-26.

Power and Strategy in Power/Knowledge. New York: Pantheon Books, 1980.

The Archaeology of Knowledge. Routledge: New York, 1987.

"Governmentality." In The Foucault Effect: Studies in Governmentality, edited by Graham Burchell, Colin Gordon \& Peter Miller. Hemel Hempstead: Harvester Wheatsheaf, 1991.

Garuba, Harry \& Sam Raditlhalo.

"Culture." In New South African Key Words, edited by Nick Shepherd \& Steven L. Robins.

Ohio: Ohio University Press, 2008.

Hall, Martin.

"Identity, Memory and Counter-Memory: The Archaeology of an Urban Landscape." Journal of Material Culture 11, no. 1-2(2006):11. 
Hall, Martin.

Desire Lines: Space, Memory and Identity in the Post-Apartheid City, London: Routledge, 2007a.

Hall, Martin.

Tourism and Post-Colonialism: Contested Discourses, Identities and Representations. London: Routledge, 2007b.

Harrison, Rodney.

Understanding the Politics of Heritage. Manchester: Manchester University Press, 2010.

Melber, Henning.

Liberation Movements as Government: The Unfinished Business of Decolonisation. In Outside the Ballot Box: Preconditions for Elections in Southern Africa 2004/5, edited by Jeanette Minnie. Windhoek: Media Institute for Southern Africa (MISA), 2006.

Melber, Henning.

The Legacy of Anti-colonial Struggles in Southern Africa: Liberation Movements as Governments. International Journal of Social Renewal, 2006.

Human Sciences Research Council (HSRC). Documenting the Legacy of the South African Liberation Struggle: The National Liberation Heritage Route, Research Report on the Liberation Heritage Route in South Africa, Democracy, Governance and Service Delivery(DGSD), 2013, http://www.hsrc.org.za or http:// www.nhc.org.za

Lalu, Premesh.

"The Virtual Stampede for Africa: Digitization, Post-Coloniality and Archives of the Liberation Struggles in Southern Africa." Innovation: Journal of Appropriate Librarianship and Information Work in Southern Africa 34 (2007): 28-44.

Leistyna, Pepi, Arlie Woodrum \& Stephen A. Sherblom.

Breaking Free: The Transformative Power of Critical Pedagogy. Cambridge, MA: Harvard Educational Review, 1999.

Lowenthal, David.

The Past is a Foreign Country. Cambridge: Cambridge University Press, 1985.

Lowenthal, David.

"The Timeless Past: Some Anglo-American Historical Preconceptions." Journal of American History, 75, no. 4(1989): 1263-1280. 
Lowenthal, David.

The Heritage Crusade and the Spoils of History. Cambridge: Cambridge University Press, 1998.

\section{MacDonald, Sharon \& Roger Silverstone.}

"Rewriting the Museums Fictions: Taxonomies, Stories and Readers." Cultural Studies 4, no. 2 (2006):176-191.

The Hashim Mbita Research Project. Southern African National Liberation Struggles. Tanzania: Mkuki Na Nyota Publishers, 2014.

Manetsi, Thabo.

Safeguarding Intangible Heritage in South Africa: A Critique of the Draft National Policy on Living Heritage. International Journal on Intangible Cultural Heritage 6, no. 57(2011).

Manetsi, Thabo.

State Prioritised Heritage: Issues of Governmentality, Institutionalisation and Monumentalisation of Heritage, A Seminar Presentation at Archaeology Centre, Stanford University, USA, 21 November, 2013.

Marschall, Sabine.

"Commemorating Struggle Heroes: Constructing a Genealogy for the New South Africa." International Journal of Heritage Studies 12, no.2 (2006a).

Marschall, Sabine.

Landscape of Memory: Commemorative Monuments, Memorials and Public Statuary in Post-Apartheid South. Leiden: Brill, 2006b.

National Heritage Council. Draft National Transformation Heritage Charter. p. 4, 2006.

National Heritage Council. Presentation of National Liberation Heritage Route project at a Summit in the North West Province. p. 6, 2011.

National Heritage Council. The National Liberation Heritage Route Report and Power Point Presentation, 2015, www.nhc.org.za

National Heritage Council. The National Liberation Heritage Route, Report and Power Point Presentation, 2016, www.nhc.org.za

\section{Ndletyana, Mcebisi.}

Patronage Politics Divide Us: A Study of Patronage, Poverty and Inequality in South Africa, Mapungubwe Institute for Strategic Reflection(MISTRA). Research Report, 2013, www.mistra.org.za 
Ndlovu, Sifiso Mxolisi.

"Heritage routes for the liberated South Africans : Using Oral History to Reconstruct Unsung Heroes and Heroines' Route into Exile in the 1960s." Historia 47, no. 2 (2002): 479-510.

\section{Ndlovu-Gatsheni, Sabelo J.}

Heritage routes for the liberated South Africans: Using Oral History to Reconstruct Unsung Heroes and Heroines' Route into Exile in the 1960s. SADET, 2002.

Ndlovu-Gatsheni, Sabelo J. \& Wendy Willems.

Making Sense of Cultural Nationalism and the Politics of Commemoration under the Third Chimurenga in Zimbabwe, Journal of Southern African Studies, 2009.

Ndlovu-Gatsheni, Sabelo J.

The Ndebele Nation: Reflections on Hegemony, Memory and Historiography. Amsterdam \& Pretoria: Rozenberg Publishers \& UNISA Press, 2009.

\section{Ndlovu-Gatsheni, Sabelo J.}

The Zimbabwean Nation-State Project: A Historical Diagnosis of Identity- and Power-Based Conflicts in a Postcolonial State. Uppsala: Nordic Africa Institute, 2010.

Ndlovu-Gatsheni, Sabelo J. Hostage to Nationalist Monologue, Recycled Histories and Sanitised Memories: The Case of Zimbabwe. Paper presented at the ECAS 2011 - 4th European Conference on African Studies, Uppsala, 2011a.

Ndlovu-Gatsheni, Sabelo J.

Reconstructing the Implication of Liberation Struggle History on SADC Mediation in Zimbabwe. African Perspectives: Global Insights 92. Wits: South African Institute of International Affairs, 2011b.

Ndoro, Webber \& Gilbert Pwiti.

Heritage Management in Southern Africa. In Heritage, Museums and Galleries: An Introductory Reader, edited by Gerard Corsane. London: Routledge, 2005. 
Negri, Vincent.

Introduction to Heritage Law in Africa. In Cultural Heritage and the Law Protecting Immovable Heritage in English-Speaking Countries of Sub-Saharan Africa, edited by Webber Ndoro, Albert Mumma \& George Abungu. ICCROM Conservation Studies, 2008.

Nelson Mandela Monuments of Liberation and Reconciliation consultative visit, National Heritage Council, 24 January 2014.

NEUM. Disinherited: Distorting heritage by Omission, NEUM report: Posted on $18^{\text {th }}$ September 2012.

Pikirayi, Innocent.

The Heritage We Want: Development, Sustainability and the Future of Africa by 2063. A Presentation at the Seminar on Harmonising Heritage with the African Union Agenda 2063 organized by the Africa World Heritage Fund. Development Bank of Southern Africa, Midrand, South Africa, 6-8 May 2015.

\section{Pickover, Alison M.}

2012. Disinherited: Distorting heritage by omission by NEUM report: Posted on 18 September 2012.

The Draft National Transformation Heritage Charter, 2009, www.nhc.org.za

The South African Heritage Resources Agency. Report on Arts, Culture and Heritage White Paper Policy Review Workshop, 11 June 2015.

Regional Workshop on the African Liberation Heritage. 2011. Roodevallei Conference and Meetings Hotel organised jointly by the Africa World Heritage Fund, Department of Arts and Culture and the National Heritage Council, 16-18 August 2011.

Report of Consultative Workshop on Liberation Heritage Route: Tourism Route Development, National Department of Tourism, Ditsong Museum, Pretoria, 22 October 2014.

Nelson Mandela Memorials of Liberation and Reconciliation Project Proposed World Heritage Nomination(NHC/04/2013/14), WHS Nomination Dossier Options Analysis Report, www.nhc.org.za

Parliamentary Monitoring Group, Arts and Culture: Minister's Budget Vote Speech, A presentation of the Budget Speech at the National Assembly by Minister of Arts and Culture, Mr Paul Mashatile, 3 May 2012, www.pmg.org.za/print/31872

Tentative List Submission Liberation Heritage Route by the Republic of South Africa, Submitting State Party Agency, National Heritage Council, 2008, www.nhc.org.za 
Smith, Laurajane.

Uses of Heritage. New York, Routledge, 2006.

State of the Nation Address By His Excellency Jacob G Zuma, President of the Republic of South Africa on the occasion of the Joint Sitting of Parliament, Cape Town, 10 February 2011. [Online]. Available: www.info.gov.za/speech /

State of the Nation Address By His Excellency Jacob G. Zuma, President of the Republic of South Africa on the occasion of the Joint Sitting of Parliament, Cape Town, 9 February 2012, www.info.gov.za/speech/

State of the Nation Address By His Excellency Jacob G, Zuma, President of the Republic of South Africa on the occasion of the Joint Sitting of Parliament, Cape Town, February 2013, www.info.gov.za/speech /

State of the Nation Address By His Excellency Jacob G Zuma, President of the Republic of South Africa on the occasion of the Joint Sitting of Parliament, Cape Town, February 2014, www.info.gov.za/speech/

State of the Nation Address By His Excellency Jacob G. Zuma, President of the Republic of South Africa on the occasion of the Joint Sitting of Parliament, Cape Town, February 2015, www.info.gov.za/speech/

State of the Province Address by Eastern Cape Premier Noxolo Kiviet, delivered on the Occasion of the Opening of the Eastern Cape Provincial Legislature, 17 February 2012, www.anc.org.za/eclcaucus/

State of the Province Address by Eastern Cape Premier Noxolo Kiviet, deliverd on the Occasion of the Opening of the Eastern Cape Provincial Legislature, 25 February 2013, www.anc.org.za/eclcaucus/

South African News Agency. Graves of Struggle Heroines Declared Heritage Sites, 2010, https://www.sanews.gov.za/south-africa/graves-struggleheroines-declared-heritage-sites

South African Tourism (SAT). Tourism satellite report for the financial year 2014/2015, 2015, www.sat.net 